\title{
An in vitro microbiological study comparing eight endotracheal tubes and their ability to prevent microaspiration
}

\author{
M Mariyaselvam*, L Marsh, M Wise, D Williams \\ From ESICM LIVES 2015 \\ Berlin, Germany. 3-7 October 2015
}

\section{Introduction}

The major cause of ventilator-associated pneumonia (VAP) is the aspiration of bacteria-laden subglottic secretions past the cuff of the endotracheal tube (ETT) [1]. When the ETT cuff is inflated to the correct wall pressure, excess cuff material folds and causes involutions thereby forming channels, which allow leakage of subglottic secretions to the lungs [2]. Now, new ETT cuffs have been designed and subglottic ports added in order to prevent microaspiration. The PneuX tube has previously been shown to prevent leakage by eliminating cuff folds and other cuffs have shown variable improvements [3].

\section{Objectives}

This study aimed to compare the properties of the new design ETTs against the PneuX and their ability to prevent leakage of a microbial contaminated solution.

\section{Methods}

Seven endotracheal tubes were compared with the PneuX tube in in vitro studies. Using a sterile technique, the distal ETT was placed inside a sterile $2 \mathrm{~cm}$ 'static model trachea' and the cuff inflated according to manufacturers' instructions. A continuous cuff pressure monitor was used if indicated by the manufacturer. Four $\mathrm{ml}$ of bacterial suspension comprising of Pseudomonas aeruginosa, Staphylococcus aureus and Candida albicans was added above the ETT cuff. The time taken and the volume of the bacterial fluid to leak past the cuff was measured. This volume was collected, serially diluted, plated on to agar media and incubated aerobically $37^{\circ} \mathrm{C}$ for $24 \mathrm{~h}$. The number of colony forming units $(\mathrm{cfu} / \mathrm{ml})$ were then determined. If an ETT did not leak, the experiment was terminated at $1 \mathrm{~h}$ and a phosphate buffer solution was injected into the space below the cuff and processed as above to determine microleaks. The experiment was repeated on 10 separate occasions for each type of ETT, with a new sterile ETT used each time.

\section{Results}

Results were analyzed with a Fisher's exact test comparing the PneuX tube to the other ETT with multiple analyses and a Bonferroni correction. Figure 1 summarizes the results, which revealed a statistically significant elimination of bacterial leakage with the PneuX ETT compared to all other ETT $(\mathrm{P}<0.05)$ with exception of the Sealguard $(P=0.09)$.

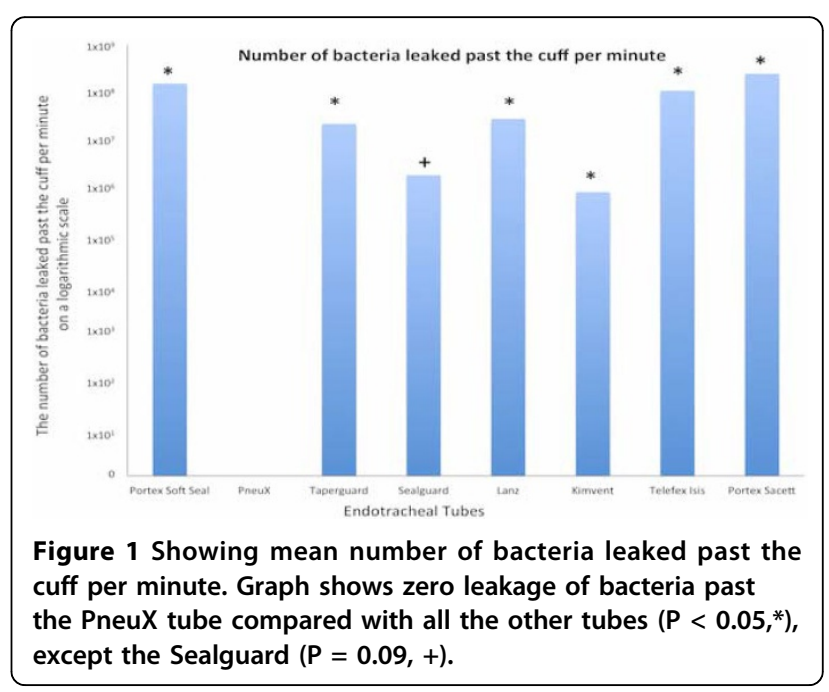




\section{Conclusions}

To reduce bacterial contamination of the lungs and prevent VAP, it is necessary for the ETT to prevent aspiration past the cuff. The PneuX was the only ETT that consistently and completly achieved this goal in this in vitro study.

\section{Grant Acknowledgment}

Funded by the Eastern Academic Health Science Network.

Published: 1 October 2015

\section{References}

1. Mietto $C$, et al: Ventilator associated pneumonia: evolving definitions and preventive strategies. Respir Care 2013, 58:990-1007.

2. Zolfaghari PS, Wyncoll DL: The tracheal tube: gateway to ventilatorassociated pneumonia, Review. Critical Care 2011, 15:310-318.

3. Young $P$, et al: A low-volume, low-pressure tracheal cuff reduces pulmonary aspiration. Crit Care Med 2006, 34:632-639.

Cite this article as: Mariyaselvam et al:: An in vitro microbiological study comparing eight endotracheal tubes and their ability to prevent microaspiration. Intensive Care Medicine Experimental 2015 3(Suppl 1):A382.

\section{Submit your manuscript to a SpringerOpen ${ }^{\circ}$ journal and benefit from:}

- Convenient online submission

- Rigorous peer review

- Immediate publication on acceptance

- Open access: articles freely available online

- High visibility within the field

- Retaining the copyright to your article 